Volume 1 Issue 1, March 2017: pp. 75-85 Copyright (c) 2017 HOLREV. Faculty of Law, Halu Oleo University, Kendari, Southeast Sulawesi, Indonesia. ISSN: 2548-1762 | e-ISSN: 2548-1754. Open Access at: http://ojs.uho.ac.id/index.php/holrev/

\title{
Kajian Filsafat Tanggungjawab Negara Terhadap Nilai-Nilai Kearifan Lokal Masyarakat Hukum Adat
}

\author{
Philosopical Analyze of State Responsibility towards Values \\ of Local Wisdom of Custom Law Society (Adatrecht)
}

\author{
Heryanti \\ Fakultas Hukum Universitas Halu Oleo \\ E-mail: heryanti.kd@gmail.com
}

\begin{abstract}
This work is intended at proposing ppropriate method in analyzing philosophically state responsibility toward value of local wisdom. This effort is importance to enrich the discourses of ethics. The ethic has become important value and part of philosophy, values, and moral in which this ethic has an abstract characteristic which dealt with good and bad. Local wisdom not only seen as merely cultural product, but also has become as sources of legal system construction which is started from philosophical understanding. For that reason, this work offers an appropriate method in analysing and integrating the local wisdom which ought to be viewed as "the law as behavior" not merely "the law as regulation, norms or principles" upon a value. The application of this method may create a holistic and integrated policy in running the state responsibility towards values of local wisdom of custom law society.
\end{abstract}

Keyword: phylosophy; state responsibility; local wisdom.

Abstrak: Karya ini ditujukan untuk menawarkan metode yang tepat dalam mengkaji secara filosofi tanggungjawab negara terhadap nilai-nilai kearifan lokal. Selama ini tanggung jawab negara hanya fokus pada problem yuris, dan mengabaikan problem etis filosofis. Penelitian ini adalah sangat penting dalam memperkaya wacana tentang etika. Etika merupakan bagian dari filsafat, nilai, dan moral yang mana etika bersifat abstrak dan berkenaan dengan persoalan baik dan buruk. Kearifan lokal tidak hanya sekedar dipandang sebagai produk kebudayaan semata, tapi harus menjadi sumber konstruksi system hukum yang bertitik tolak dari pemahaman filosofis. Dengan alasan tersebut, karya ini menawarkan suatu metode yang tepat dalam mengkaji dan mengintegrasikan kearifan lokal harus dipandang sebagai sebuah "hukum sebagai perilaku", bukan semata "hukum sebagai aturan, norma atau asas" atas suatu nilai. Aplikasi metode tersebut dapat menciptakan suatu kebijakan yang holistik yang diintegrasikan 
alam menjalankan tanggugjawab negara terhadap nilai-nilai kearifan lokal masyarakat hukum adat.

Kata kunci: filososi; tanggung jawab negara; kearifan lokal.

\section{PENDAHULUAN}

Dalam dunia hukum, ada pameo menyatakan "ubi societas ibi ius" yang memiliki makna "dimana ada masyarakat, disana ada hukum". Bagaimanapun bentuk dan apapun namanya, hukum yang diterapkan pada suatu komunitas, baik dalam bentuknya yang paling modern hingga paling primitif sekalipun, sesungguhnya berangkat dari kesadaran hukum.

Ewick dan Sylbey merumuskan kesadaran hukum mengacu kepada cara-cara dimana orang-orang memahami hukum dan institusi-institusi hukum, yaitu pemahamanpemahaman yang memberikan makna kepada pengalaman dan tindakan orang-orang. Bagi Ewick dan Sylbey, kesadaran hukum terbentuk dalam tindakan dan karenanya merupakan persoalan praktik untuk dikaji secara empiris. Dengan kata lain, kesadaran hukum adalah persoalan "hukum sebagai perilaku" dan bukan "hukum sebagai aturan, norma atau asas"1.

Kemajuan hukum suatu bangsa merupakan cerminan tingkat kesadaran hukum warganya. Semakin tinggi kesadaran hukum warga negara, maka semakin tertib kehidupan bermasyarakat dan bernegara. Sedemikian pentingnya kesadaran hukum ini sehingga Hugo Krabbe (1857-1936), menyatakan bahwa sumber segala hukum adalah kesadaran hukum. Kesadaran hukum merupakan faktor dalam penemuan hukum. Menurut pendapatnya, yang disebut hukum hanyalah yang memenuhi kesadaran hukum kebanyakan orang. Oleh karena itu, undang-undang yang tidak sesuai dengan kesadaran hukum kebanyakan orang akan kehilangan kekuatan mengikat ${ }^{2}$.

Di kekinian, kearifan lokal mulai dikaji sebagai bentuk kesadaran hukum. Kearifan lokal sebagai sebuah kekayaan luhur bangsa, selama ini tenggelam dalam gegap gempita modernisasi. Padahal, kearifan lokal -seperti kata Ewick dan Sylbey- lebih merupakan hukum sebagai perilaku bukan sebagai aturan, norma, atau asas. Karena konteksnya

1 Ewick dan Sylbey dalam Achmad Ali, 2009, Menguak Teori Hukum (Legal Theory) dan Teori Peradilan (Judicialprudence) Termasuk Interpretasi Undang-Undang (Legisprudence), Kencana, Jakarta, hlm. 298.

2 Singkeru Rukka, Kearifan Lokal dan Kesadaran Hukum, Jurnal Al Risalah Volume 13 Nomor 1 Mei 2013, hlm. 174. 
sebagai perilaku, maka daya ikat kearifan lokal terhadap anggota komunitas (masyarakat)-nya menjadi sangat kuat.

Dalam konsepsi penegakan hukum, penekanannya selalu berorientasi pada aspek penegakan undang-undang. Menurut Budimansyah, asumsi seperti ini sangat keliru karena hukum harus dilihat dalam suatu sistem yang bekerja saling berkaitan satu sama lain. Sistem hukum tidak hanya mengacu pada aturan (codes of rules) dan pengaturan (regulations), namun mencakup bidang yang luas meliputi struktur, lembaga, dan proses (procedure) yang mengisinya, serta terkait dengan hukum yang hidup di dalam masyarakat (living law), termasuk di dalamnya adalah kearifan lokal (local wisdom) serta budaya hukum (legal culture) ${ }^{3}$.

Dalam kehidupan bernegara, penulis mengutip kegelisahan hati Sudjito bin Atmoredjo tentang realitas penegakan keadilan saat ini. Dengan hati yang risau dia menulis, jangan-jangan ilmu hukum yang dipelajari dan diajarkan kepada peserta didik ataupun masyarakat luas itu ada yang salah. Jangan-jangan langkanya dan sulitnya perolehan keadilan oleh masyarakat di negeri ini, terpulang dari ilmu hukum yang bermasalah. Jangan-jangan ilmu hukum yang dipraktikkan oleh para aparat penegak hukum itu tergolong ilmu hukum yang mengandung benih-benih penyakit yang membikin kehidupan bermasyarakat menjadi tidak sehat ${ }^{4}$.

Berangkat dari latar belakang di atas, tulisan ini mencoba mengeksplorasi nilainilai kearifan lokal pada masyarakat adat dalam pendekatan filsafat untuk diserap sebagai salah satu sistem hukum dalam konteks pengaturan (regulations) dan aturan (codes of rules).

\section{METODE PENELITIAN}

Tipe penelitian ini adalah penelitian hukum normatif. Menurut Bernard Arief Sidharta bahwa penelitian hukum normatif (dogmatik hukum, rechtsdogmatiek), kegiatan ilmiahnya mencakup inventarisasi, memaparkan, interpretasi, dan sistematisasi termasuk evaluasi keseluruhan hukum positif (teks otoritatif) yang berlaku dalam masyarakat atau Negara .

3 Budimansyah, 2013, Kearifan Lokal Sebagai Aspek Penegakan Hukum Untuk Keadilan Yang Substansi, Jurnal Fakultas Hukum Universitas Panca Bhakti Tahun 2013.

4 Sudjito bin Atmoredjo, 2011, Pancasila Sebagai Paradigma Ilmu Hukum Indonesia, Kumpulan Makalah Seminar Hukum dan Konstitusi "Pancasila untuk Pengembangan dan Pengamalan Ilmu Hukum", Pusat Studi Pancasila UGM, Yogyakarta, hlm. 1 
Jenis data yang digunakan adalah data sekunder yaitu data penelitian yang diperoleh dari kepustakaan. Pengumpulan data dalam penelitian dilakukan dengan metode dokumentasi, dan alat mengumpulkan data dilakukan melalui studi dokumen.

Metode yang dipakai menganalisis data adalah metode kualitatif yaitu suatu analisis secara mendalam dan komprehensif. Pertimbangan metode kualitatif didasarkan pada pertimbangan bahwa data yang dianalisis beragam macamnya serta sifat dasar tiap-tiap data berbeda-beda .

\section{ANALISIS DAN PEMBAHASAN}

\section{Kajian Filsafat Terhadap Nilai-Nilai Kearifan Lokal Masyarakat Hukum Adat}

Filsafat termasuk ilmu pengetahuan yang paling luas cakupannya. Secara etimologi, istilah filsafat dalam Bahasa Indonesia memiliki padanan kata falsafah (Arab), philosophy (Inggris), philosophia (Latin), philosopie (Jerman, Belanda, Perancis). Semua istilah itu bersumber pada istilah Yunani, philosophia. Istilah Yunani philen berarti mencintai, sedangkan philos berarti teman. Selanjutnya, isitlah shopos berarti bijaksana, sedangkan shopia berarti kebijaksanaan ${ }^{5}$.

Filsafat merupakan usaha untuk memperoleh pandangan yang menyeluruh. Filsafat mencoba menggabungkan kesimpulan-kesimpulan dari berbagai ilmu dan pengalaman manusia menjadi suatu pandangan dunia yang konsisten. Para filsuf berhasrat meninjau kehidupan tidak dengan sudut pandangan khusus sebagaimana dilakukan oleh seorang ilmuwan. Para filsuf memakai pandangan yang menyeluruh terhadap kehidupan secara totalitas ${ }^{6}$.

Dalam kaitannya dengan filsafat, kearifan lokal masyarakat adat masuk dalam diskursus tentang etika. Etika merupakan dunianya filsafat, nilai, dan moral yang mana etika bersifat abstrak dan berkenaan dengan persoalan baik dan buruk. Dapat disimpulkan bahwa etika adalah: (1) ilmu tentang apa yang baik dan apa yang buruk dan terutama tentang hak dan kewajiban moral; (2) kumpulan asas atau nilai yang berkenaan

5 Mohammad Zamroni, 2009, Filsafat Komunikasi: Pengantar Ontologis, Epistemologis, Aksiologis, Graha Ilmu, Yogyakarta, hlm. 26.

6 Ibid, hlm. 26-27. 
dengan akhlak; (3) nilai mengenai benar atau salah yang dianut suatu golongan atau masyarakat7. (Wibisono, dkk, 2013).

Pada level aliran filsafat, etika bisa dilihat sebagai model rasionalitas tindakan, misalkan aliran teleologis atau aliran deontologis. Aliran Etika Teleologis sendiri berasal dari Etika Aristoteles. Aliran etika teleologis adalah etika yang mengukur benar/salahnya tindakan manusia dari menunjang tidaknya tindakan tersebut ke arah pencapaian tujuan (telos) akhir yang ditetapkan sebagai tujuan hidup manusia. Setiap tindakan menurut Aristoteles diarahkan pada suatu tujuan, yakni pada yang baik (agathos).

Dalam perkembangannya, etika ini disempurnakan kembali oleh John Stuart Mill dan Jeremy Bentham, lewat perspektif Utilitarianisme yang berasal dari bahasa Inggris "utility" yang berarti kegunaan, berguna, atau guna. Dengan demikian, suatu tindakan harus ditentukan oleh akibat-akibatnya. Dilihat dari pengertian di atas, maka ciri umum aliran ini adalah bersifat kritis, rasional, teleologis, dan universal. Utilitarinisme sebagai teori etika normatif merupakan suatu teori yang kritis, karena menolak untuk taat terhadap norma-norma atau peraturan moral yang berlaku begitu saja dan sebaliknya menuntut agar diperlihatkan mengapa sesuatu itu tidak boleh atau diwajibkan.

Sementara itu, aliran deontologis melihat bahwa kerangka tindakan/perilaku manusia dilihat sebagai kewajiban. Kata deon berasal dari Yunani yang artinya kewajiban. Sudah jelas kelihatan bahwa teori deontologi menekankan pada pelaksanaan kewajiban. Suatu perbuatan akan baik jika didasari atas pelaksanaan kewajiban, jadi selama melakukan kewajiban berarti sudah melakukan kebaikan. Deontologi tidak terpasak pada konsekuensi perbuatan, dengan kata lain deontologi melaksanakan terlebih dahulu tanpa memikirkan akibatnya. Hal-hal yang lain seperti kekayaan, intelegensia, kesehatan, kekuasaan dan sebagainya disebut sebagai kebaikan yang terbatas, yang baru memiliki arti manakala ia dipakai oleh kehendak baik manusia ${ }^{8}$.

Sebagai sistem pemikiran tentunya konsep dasar filsafat digunakan dalam mengkaji etika dalam sebuah hubungan keseimbangan antara cipta, rasa, dan karsa. Hubungan tersebut didasari landasan pemikiran ontologi, epistemologi, dan aksiologi. Ontologi yaitu apakah hakikat pemikiran tersebut, epistemologi yaitu mengapa ada

\footnotetext{
7 H.K. Wibisono, L.N. Trianita, dan Sri Widagdo, 2013, Dimension of Pancasila Ethics In Bureaucracy: Discourse of Governance (Filsafat, Etika, dan Kearifan Lokal untuk Konstruksi Moral Kebangsaan), Globethics.net, Geneva, hlm. 18.

8 Ibid, hlm. 19.
} 
pemikiran tersebut, sementara aksiologi adalah bagaimana cara untuk melaksanakan pemikiran tersebut.

Kant menolak pandangan moral kaum utilitarianisme yang mengedepankan tujuan yang ingin dicapai sebagai landasan moral dari suatu perbuatan. Bagi Kant, suatu perbuatan dinilai baik manakala dilakukan atas dasar kewajiban, yang disebutnya sebagai perbuatan berdasarkan legalitas, tidak penting untuk tujuan apa perbuatan itu dilakukan. Ajaran ini menekankan bahwa seharusnya kita melakukan "kewajiban" karena itu merupakan "kewajiban" kita, dan untuk itu alasan (reason) tidak diperlukan sehingga perbuatan itu dilakukan.

Suseno mencontohkan tentang hubungan antara etika dan norma. Dalam konteks masyarakat tradisional, orang kelihatan dengan sendirinya menaati adat-istiadat. Sebab, mereka telah membatinkan (menginternalisasikan) norma-normanya. Mereka menaati norma-norma tersebut, bukan karena takut dihukum, melainkan karena ia akan merasa bersalah apabila ia tidak mentaatinya. Norma-norma penting dari masyarakat telah ditanam dalam batin setiap anggota masyarakat itu sebagai norma moral ${ }^{9}$.

Norma yang tertanam dan menjadi panduan perilaku masyarakat adat (tradisional) ditafsir sebagai kearifan lokal. Hukum positif yang berkembang di Indonesia sangat minim (atau malah sama sekali tidak) menjadikan nilai-nilai kearifan lokal sebagai landasan dalam proses penyusunannya. Seperti kata Satjipto Rahardjo, ilmu hukum yang berkembang di Indonesia saat ini hanya cenderung menjadi ilmu praktis (practical science), dan bukan (belum) merupakan ilmu hukum sebagai sebenar ilmu (genuine science). Dinyatakan bahwa, “ ... kita telah terjebak pada konsep hukum para profesional yang disebut "lawyer's law, "law for the lawyers" atau "law for the professionals" ... ", suatu konsep hukum yang lahir dari pemikiran kaum positivis, yang hanya mau mengakui kebenaran itu pada hal-hal yang praktis, yaitu realitas yang pasti, bisa dibuktikan, dan bisa diterima akal (logika). Ilmu hukum sebagai practical science, bekerja menggarap teks-teks normatif yang disebut hukum positif. Inilah jenis hukum yang sering disebut pula dengan istilah "hukum negara", "hukum modern", ataupun "perundang-undangan". Ia tidak menggarap hukum dari realitas yang utuh, melainkan sebatas realitas yang logisrasional saja. Identik dengan pemikiran Newtonian-yaitu pemikiran yang mempersepsikan manusia modern adalah makhluk otonom dan rasional yang hidup dalam dunia mekanis, serta melihat alam sebagai suatu bangunan yang sistematis,

9 Franz Magnis Suseno, 1992, Filsafat Sebagai Ilmu Kritis, Kanisius, Yogyakarta, hlm. 26. 
mekanistis, linier dan deterministic-maka para positivis juga menghendaki agar hukum modern itu harus rasional, sistematis dan logis ${ }^{10}$.

Konstruksi hukum yang menafikan genuine science dan hanya lebih pada practical science pada gilirannya hanya memberikan kepastian hukum, tetapi tidak melayani kebutuhan akan keadilan. Hal ini sejalan dengan filsafat hukum yang berkisar pada tiga nilai dasar hukum yang diuraikan oleh Gustav Radbruch (1878-1949) yaitu keadilan, kegunaan, dan kemanfaatan hukum. Masyarakat tidak hanya butuh peraturan-peraturan yang menjamin kepastian hukum dalam hubungan mereka satu sama lain, tetapi juga butuh keadilan di samping hukum dituntut pula melayani kepentingan-kepentingannya (memberikan kemanfaatan) ${ }^{11}$. Nilai dasar "kegunaan” yang dikemukakan Gustav ini, kata Satjipto Rahardjo, menempatkan hukum dalam kaitan dengan konteks sosial yang lebih besar. Dengan demikian, hal ini menjadi pembuka jalan bagi kajian hukum yang juga memperhatikan interaksi antara hukum dan masyarakatnya ${ }^{12}$. Di sinilah terdapat ruang bagi kelompok masyarakat adat dengan nilai kearifan lokal yang melekat padanya untuk dapat diterima sebagai dasar konstruksi hukum.

Dalam kehidupan sosial kemasyarakatan, ada pandangan Talcott Parsons melalui tulisannya berjudul "The Law and Social Control" yang terinspirasi oleh pandangan Max Weber. Dalam tulisannya, dia menyimpulkan bahwa fungsi utama suatu sistem hukum tidak lain untuk mengatur, memelihara dan atau menjaga hubungan-hubungan sosial dalam suatu sistem sosial. Dalam hubungannya dengan pembangunan, peran sentral hukum difokuskan pada tiga (3) hal, yaitu (1) hukum sebagai alat penertib (ordering), (2) hukum sebagai alat penjaga keseimbangan (balancing), dan (3) hukum yang berfungsi sebagai katalisator yang berfungsi menjaga keseimbangan dan keharmonisan kepentingan-kepentingan yang ada ${ }^{13}$.

Konsepsi yang ketiga ini sejalan dengan eksistensi nilai-nilai kearifan lokal pada masyarakat adat. Kearifan lokal diterapkan dengan sangat halus pada anggotanya. Sebagai contoh, masyarakat Suku Bajo di Kabupaten Buton Utara, Sulawesi Tenggara,

10 Satjipto Rahardjo dalam Sudjito bin Atmoredjo, 2011, Pancasila Sebagai Paradigma Ilmu Hukum Indonesia, Kumpulan Makalah Seminar Hukum dan Konstitusi "Pancasila untuk Pengembangan dan Pengamalan Ilmu Hukum", Pusat Studi Pancasila UGM, Yogyakarta, hlm. 6.

11 Teguh Prasetyo dan Abdul Halim Barakatullah, 2013, Filsafat, Teori, dan Ilmu Hukum: Pemikiran Menuju Masyarakat yang Berkeadilan dan Bermartabat, Raja Grafindo Persada, Jakarta, hlm. 15-16.

12 Satjipto Rahardjo, 2010, Sosiologi Hukum: Perkembangan Metode dan Pilihan Masalah, Genta, Yogyakarta, hlm. 17-18.

13 Dossy Iskandar Prasetyo dan Bernard L. Tanya, 2011, Hukum Etika dan Kekuasaan, Genta, Yogyakarta, hlm. 102-103. 
meyakini bahwa ketika sedang melaut dan mendapati teripang yang berdiri tegak (tidak melata), maka jangan ditangkap. Dalam kepercayaan masyarakat Suku Bajo di daerah itu, teripang yang dalam kondisi berdiri dapat mendatangkan bala jika ditangkap. Dalam beberapa keyakinan masyarakat setempat, teripang yang berdiri tegak merupakan salah satu ciri-ciri dari proses reproduksi. Secara tersirat, masyarakat Bajo melarang penangkapan teripang yang sedang berkembang biak untuk melestarikan kelangsungan hidupnya.

Sartini yang mengutip tulisan berjudul "Pola Perilaku Orang Bali Merujuk Unsur Tradisi” yang diterbitkan Balipos edisi 4 September 2003, memaparkan beberapa fungsifungsi dari kearifan lokal, yaitu:

1. Konservasi dan pelestarian sumber daya alam

2. Pengembangan sumber daya manusia

3. Pengembangan kebudayaan dan ilmu pengetahuan

4. Petuah, kepercayaan, sastra dan pantangan

5. Bermakna sosial

6. Bermakna etika dan moral

7. Bermakna politik ${ }^{14}$.

Fungsi kearifan lokal yang multidimensional ini menunjukkan bahwa kearifan lokal merupakan modal sosial yang fundamental dalam mengkonstruksi sistem hukum.

\section{Kajian Filsafat Tanggung Jawab Negara Terhadap Nilai-Nilai Kearifan Lokal Masyarakat Hukum Adat}

Mochtar Kusumaatmadja mengaitkan hukum dengan kekuasaan yang dirumuskan dalam slogan ringkas "hukum tanpa kekuasaan adalah angan-angan, kekuasaan tanpa hukum adalah kelaliman". Dalam penerapannya, hukum memerlukan suatu kekuasaan untuk mendukungnya. Ciri utama inilah yang membedakan antara hukum di satu pihak dengan norma-norma sosial lainnya dan norma agama. Kekuasaan itu diperlukan karena hukum bersifat memaksa. Tanpa adanya kekuasaan, pelaksanaan hukum di masyarakat akan akan mengalami hambatan-hambatan. Semakin tertib dan teratur suatu masyarakat, makin berkurang diperlukan dukungan kekuasaan ${ }^{15}$.

14 Sartini, 2004, Menggali Kearifan Lokal Nusantara Sebuah Kajian Filsafati, Jurnal Filsafat, Agustus 2004, Jilid 37, Nomor 2 hlm 112-113.

15 Mochtar Kusumaatmadja dalam Lili Rasjidi dan Ira Rasjidi, 2001, Dasar-Dasar Filsafat dan Teori Hukum, Citra Aditya Bakti, Bandung, hlm. 75 
Pertanyaan kemudian yang muncul adalah bagaimana tanggung jawab negara yang merupakan representasi kekuasaan untuk mewujudkan nilai-nilai kearifan lokal dalam sistem hukum? Pertanyaan ini berangkat dari aliran filsafat tertua, yakni teori hukum alam. Dalam teori ini, hukum dianggap sebagai nilai yang universal dan selalu hidup di setiap sanubari orang, masyarakat maupun negara. Hal ini disebabkan karena hukum niscaya harus tunduk pada batasan-batasan moral yang menjadi guideline bagi hukum itu sendiri. Bahkan disebutkan bahwa di atas sistem hukum positif negara, ada sebuah sistem hukum yang lebih tinggi (lex divina), bersifat Ketuhanan yang berdasarkan atas akal budi atau hukum alam itu sendiri, jadi hukum alam lebih superior dari hukum negara ${ }^{16}$.

Sudjito bin Atmoredjo menyatakan bahwa selama ini memang ada permasalahan dalam ilmu hukum, terutama pada penolakan terhadap semua hal-hal yang bersifat teologis dan metafisis. Kebudayaan atau nilai-nilai sosial, yang salah satunya dikenal sebagai kearifan lokal itu, sangat lekat dengan aspek-aspek ketuhanan ${ }^{17}$.

Sebelumnya, Adumiharjo Kusnaka mengakui bahwa para perencana pembangunan di Indonesia menganggap nilai budaya masyarakat sebagi simbol keterbelakangan. Paham ini membuat nilai-nilai tradisional yang tercermin dalam kearifan lokal tercerabut dan/atau tak terakomoodir dalam berbagai produk peraturan, perundangan dan kebijakan-kebijakan lainnya. Dampaknya, terjadi eksploitasi alam yang berlebihan, dan hancurnya tatanan lingkungan, serta marjinalisasi masyarakat adat yang mengarah pada pemiskinan hak ekonomi, hukum, sosial agama dan politik ${ }^{18}$.

Kesadaran inilah yang seharusnya mengisi ruang-ruang pikir para penyusun regulasi, baik dalam tataran lembaga eksekutif, legislatif, maupun yudikatif. Dengan demikian, kearifan lokal tidak hanya dipandang sebagai sebuah produk eksotis yang dilihat dengan penuh rasa keheranan. Kearifan lokal tidak lagi dipandang laksana artefak-artefak masa lalu yang dipajang di ruang-ruang museum. Negara harus menjadikan kearifan lokal sebagai salah satu landasan fundamental dalam menyusun produk-produk hukum positif.

6 Op.cit, Teguh Prasetyo dan Abdul Halim Barakatullah, hlm. 90-91

17 Op. Cit, Sudjito bin Atmoredjo, hlm. 7

18 Adimiharjo Kusnaka, 1999. Hak Sosial Budaya Masyarakat Adat, dalam Menggugat Posisi Adat terhadap Negara, (Jakarta: Lembaga Studi Pers dan Pembangunan). 


\section{KESIMPULAN}

Kajian filsafat terhadap nilai-nilai kearifan lokal masyarakat hukum adat bahwa masyarakat adat dengan berbagai nilai kearifan lokal yang melekat padanya merupakan kekayaan bangsa ini yang harus dilestarikan. Tidak hanya sekadar untuk melihatnya sebagai produk kebudayaan semata, tapi kearifan lokal harus menjadi sumber konstruksi sistem hukum yang berangkat dari pemahaman filosofis. Bahwa kearifan lokal harus dipandang sebagai sebuah "hukum sebagai perilaku", bukan semata "hukum sebagai aturan, norma atau asas". Di tengah modernisasi yang berlangsung saat ini, ilmu hukum yang berkembang hanya menjadi practical science, dan belum menjadi qenuine science atau sebenar-benarnya ilmu. Kearifan lokal dapat dipandang sebagai nilai-nilai yang bersifat teologis dan metafisis yang bermuara pada kebenaran yang hakiki.

Kajian filsafat tanggung jawab negara terhadap nilai-nilai kearifan lokal masyarakat hukum adat bahwa negara harus mengubah paradigma yang melihat masyarakat adat dengan nilai-nilai kearifan lokalnya sebagai simbol keterbelakangan. Sesungguhnya kearifan lokal menyimpan potensi besar yang akan mengubah wajah penegakan hukum di Indonesia. Negara harus mengadopsi dan menyerap nilai-nilai kebijaksanaan yang terkandung dalam masyarakat adat sebagai landasan sistem hukum nasional kita untuk mencapai keadilan substantif.

\section{Daftar Pustaka}

\section{Buku}

Ali, Achmad, Menguak Teori Hukum (Legal Theory) dan Teori Peradilan (Judicialprudence) Termasuk Interpretasi Undang-Undang (Legisprudence), Jakarta: Kencana 2009. Atmoredjo, Sudjito bin, Pancasila Sebagai Paradigma Ilmu Hukum Indonesia, Kumpulan Makalah Seminar Hukum dan Konstitusi "Pancasila untuk Pengembangan dan Pengamalan Ilmu Hukum", Yogyakarta: Pusat Studi Pancasila UGM 2011. Irianto, Sulistyowati dan Shidarta (editor), Metode Penelitian Hukum; Konstelasi dan Refleksi, Jakarta: Yayasan Pustakan Obor Indonesia 2011.

Keraf, A.S., Etika Lingkungan Hidup, Jakarta: Buku Kompas 2010.

Kusnaka, Adimiharjo, Hak Sosial Budaya Masyarakat Adat, dalam Menggugat Posisi Adat terhadap Negara, Jakarta: Lembaga Studi Pers dan Pembangunan 1999.

Muhammad, Abdul Kadir, Hukum dan Penelitian Hukum, Bandung: PT Citra Aditya Bakti, 2004. 
Prasetyo, Dossy Iskandar dan Bernard L. Tanya, Hukum Etika dan Kekuasaan, Yogyakarta: Genta 2011.

Prasetyo, Teguh dan Abdul Halim Barakatullah, Filsafat, Teori, dan Ilmu Hukum: Pemikiran Menuju Masyarakat yang Berkeadilan dan Bermartabat, Jakarta: Raja Grafindo Persada 2013.

Rahardjo, Satjipto, Sosiologi Hukum: Perkembangan Metode dan Pilihan Masalah, Yogyakarta: Genta 2010.

Rasjidi, Lili dan Ira Rasjidi, Dasar-Dasar Filsafat dan Teori Hukum, Bandung: Citra Aditya Bakti 2001.

Rosidi, Ajip, Kearifan Lokal Dalam Perspektif Budaya Sunda, Bandung: Kiblat Buku Utama 2011.

Suhandi, dkk, Tata Kehidupan Masyarakat Baduy di Propinsi Jawa Barat, Bandung: Departemen Pendidikan dan Kebudayaan Proyek Inventarisasi dan Dokumentasi Kebudayaan Daerah 1987.

Suseno, Franz Magnis, Yogyakarta: Filsafat sebagai Ilmu Kritis, Kanisius 1992.

Wibisono, H.K., L.N. Trianita, dan Sri Widagdo, Dimension of Pancasila Ethics In Bureaucracy: Discourse of Governance (Filsafat, Etika, dan Kearifan Lokal untuk Konstruksi Moral Kebangsaan). Geneva: Globethics.net 2013.

Zamroni, Mohammad, Filsafat Komunikasi: Pengantar Ontologis, Epistemologis, Aksiologis, Yogyakarta: Graha Ilmu 2009.

\section{Jurnal}

Budimansyah, Kearifan Lokal sebagai Aspek Penegakan Hukum untuk Keadilan yang Substansi, Jurnal Fakultas Hukum Universitas Panca Bhakti, 2013.

Sartini, Menggali Kearifan Lokal Nusantara Sebuah Kajian Filsafati, Jurnal Filsafat, Agustus 2004, Jilid 37, Nomor 2, 2004. 